\title{
Constraints on Property Rating in the Offinso South Municipality of Ghana
}

\author{
Commonwealth Journal of Local Governance \\ Issue 13/14: November 2013 \\ http://epress.lib.uts.edu.au/ojs/index.php/cjlg
}

\author{
Nicholas Addai Boamah \\ University for Development Studies \\ WA Campus, Ghana \\ Email: addaianas@yahoo.co.ug
}

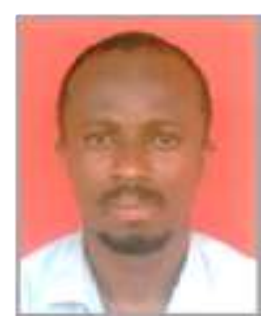

\begin{abstract}
The potential of property rate has been least tapped by decentralized governments in Ghana. This paper investigates the property rating system in Ghana through a case study of Offinso South Municipality (OSM). Questionnaires were used to gather empirical data from property owners in the municipality. The paper finds that there is inadequate property tax administration system and high public disdain for the property tax in OSM, with a significant association between compliance with the property tax and land use regulations in OSM. The paper suggests that the Offinso South Municipal Assembly (OSMA) should improve its land use planning system to facilitate voluntary compliance with the property tax. OSMA should also address accountability and transparency problems in the property tax system in order to increase public confidence in the tax regime. The OSMA should also improve on the property tax collection modes by computerising the billing and collection processes.
\end{abstract}

Keywords: property rate, land use planning, public disdain, Offinso South Municipality, Ghana

\section{Introduction}

Decentralization is generally expected to promote greater transparency, accountability, probity, and efficiency in urban services provision. It is expected to incorporate local needs and conditions and national objectives in the planning and delivery of public services (Keith and McCluskey, 2004). Efficiency, effectiveness and legitimacy concerns are the main drivers of decentralization (McCluskey and Bevc, 2007). Local authorities that facilitate broad based participation in governance, are more responsive to local needs and more capable of appropriately addressing local challenges (Baldersheim et al., 1995). The autonomy provided by internally generated funds is of extreme importance to the well-being of decentralized governments (Livingstone and Charlton, 1998). This is essential for the success of any decentralization programme. Fiscal decentralization and local governance lead to the realization of improved economic efficiency and accountability in a country (Kelly, 2000). Fiscally a decentralized system has the potential of maximising efficiency (Okrah and Boamah, 2013). Fiscal autonomy for local governments however, depends on the efficacy of tax instruments at the disposal 
of local bodies, the growth potential of non-tax revenues and principled inter-governmental transfers (Kapoor and Ghosh, 1992). An efficient tax system provides a predictable revenue stream, has a limited administrative burden and is fair (Bell, 1999).

Property rate is the most common, dependable and sustainable source of revenue to local governments worldwide. It is one of the most lucrative sources of local government financing (Mou, 1996). It is thus essential for the success of fiscal decentralization and the financing of local infrastructure and service delivery. For instance, it is a key source of revenue for local authorities in most OECD countries (Hefferan and Boyd, 2010). Property taxes constitute 100\% of local tax revenue in Australia and Ireland, 99\% in the United Kingdom, 93\% in Canada and 72\% in the United States (Braid, 2005), and the tax forms more than $2 \%$ of developed countries GDP (Bahl, 2009).

Despite the immense contribution of property tax in developed nations, its potential is generally under-exploited in developing countries (Lall and Deichmann, 2006). Property tax revenue constitutes less than $4 \%$ of all tax revenues in developing and transitional countries, and averages $0.42 \%$ and $0.54 \%$ of Gross Domestic Product (GDP) of developing and transitional countries respectively (Kaiser, 2005; Bahl, 2009). There are low rates of property tax collections across a sample of municipal corporations in India (Rao and Ravindra, 2002). The tax accounts for less than $10 \%$ of local revenues in the Punjab province of Pakistan (Ellis, et al., 2007). It is about $80 \%$ of local government revenue in Thailand, but its potential is highly under-exploited (Varanyuwatana, 1999). Property taxation raises about $27 \%$ of local government tax revenue in 52 municipalities in Latin America (De Cesare, 2004). It forms about $22 \%$ of total recurrent revenues of local authorities, $1.3 \%$ of total government tax revenue, and $0.3 \%$ of GDP in Kenya (Kelly, 2000).

Property rate has been employed by various governments of Ghana since the colonial era. Several statutes have been passed for the regulation of property rating in Ghana. These include the Municipal Rating (Immovable Property Rate) Regulations (L.I. 212), 1959; the Local Government (Immovable Property Rate) Regulations (L.I. 40), 1960; the Local Government (Immovable Property Rate) Amendment Regulations (L.I. 348), 1964; the Municipal Rating (Immovable Property Rate) Amendment Regulations (L.I. 349), 1964; the Municipal Rating (Immovable Property Rate) Amendment Regulations (L.I. 650), 1970; the Immovable Property Rate Amendment Regulations (L.I. 1049), 1975; and the Local Government Act (Act 462), 1993. In Ghana, section 94 of Act 462 makes Metropolitan, Municipal and District Assemblies (MMDA) the rating authorities in their areas of jurisdiction. The Act 462 has therefore assigned powers of determining, levying and collecting property rate to the MMDAs in the country. Section 95 (1) states that:

A District Assembly (DA) shall make and levy sufficient rates to provide for that part of the total estimated expenditure to be incurred by it during the period in respect of which the rate is levied and which is to be met out of money raised by rates. 
Despite this legal backing and the potential of property rates to raise revenue for local development and services delivery, the MMDAs have not been able to mobilize property rate effectively and efficiently. The result is that the MMDAs in Ghana rely on central government transfers such as the District Assemblies Common Fund (DACF) as their main source of funds. Since property rates are levied only on fixed property in Ghana, it should be relatively easy for the MMDAs to mobilize property rates compared to market tolls. Also, the stock and quality of immovable properties continue to increase thereby continuously enhancing the revenue potential of property rates. It is therefore an irony that the MMDAs should leave such a huge and guaranteed revenue potential untapped and rather focus on the DACF. Discussion with rating officials shows that most properties have either not been valued or re-valued over a long period of time; local authorities are either unwilling or incapable of mobilizing property rates and tax payers are reluctant to pay.

The contribution of property tax to government revenue is negligible in Ghana; it formed $0.21 \%$ of decentralized government's revenue correspondingly in 1997 and $0.19 \%$ in 1999 , and only $0.03 \%$ of the country's' GDP in 2010 (Kwakye, 2010; Government of Ghana, 2011). Property tax contributed $10.8 \%$ of the total revenue of the Accra Metropolitan Assembly (AMA) in 2004 and $7.6 \%$ in 2005 (Adem and Kwateng, 2007). Data from the Kumasi Metropolitan Authority (KMA) show that property rate raised 5.6\% of the KMA's total revenue in 2006 (Obeng-Odoom, 2010). Available data from the Wa Municipal Assembly (WMA) suggest that the WMA was only able to mobilize 58.56\% of its projected property rate revenue in 2004 and $88.51 \%$ in 2008. In the Offinso South Municipality (OSM) available data show that the contribution of property rate to local revenue was less than $9 \%$ over the 2005 to 2009 period. Also, the Offinso South Municipal Assembly (OSMA) was only able to realize $24.21 \%, 75.65 \%$ and $71.78 \%$ of its projected property rate revenue in 2005, 2006 and 2008 respectively. Less than $40 \%$ of taxable properties in OSM are on OSMA's tax roll. Both the coverage and collection ratios appear low in the OSM.

\section{Scope and methodology}

The paper investigates the property rate regime in OSM. It solicits the perceptions of property owners on the property rate system, and investigates residents' willingness to pay and their expectations from property rate. The paper again examines any possible link between the planning regime and the level of compliance to property rate payments. Field data were gathered in the Offinso South Municipality through questionnaires. Eight neighbourhoods from the municipality were selected for data collection through random sampling. Random sampling was again employed to select fifteen non-exempt properties from each of the sampled neighbourhoods. Due to the poor numbering of properties in some of the selected neighbourhoods, in five neighbourhoods properties were renumbered to ease the data collection exercise. A total of 120 rateable properties were surveyed, and interviews held with owners of these properties, as the responsibility for paying property rates in OSM falls on the property 
owner. Data were obtained from the respondents through questionnaires. The Municipal Budget Officer (MBO) and the Chief Revenue Superintendent (CRS) were also interviewed due to their knowledge and direct role in property rating.

\section{The study area}

The study area is the Offinso South Municipality (OSM), located $17 \mathrm{~km}$ North-West of Kumasi, the second city of Ghana, administrative capital of the Ashanti Region and seat of the Asante Kingdom. The municipality has a land area of $1,350 \mathrm{~km}^{2}$, a population of 138,676 , and a population density of 103 people/km² in 2000 (Ghana Statistical Service (GSS), 2005). Individual families own properties which are mainly not for sale due to tradition and inheritance is matrilineal. A family consists of both the living and the dead of the same maternal lineage. All family properties belong to the dead, the living and the unborn. This forms the basis of the general non-disposability of family properties in the OSM. The living are obliged to protect property for themselves, the dead and the unborn. The fear of ancestral retribution (nsamantoa) generally reinforces the non-disposability of family property (Boamah, 2012).

\section{Property rate and local governance}

Rising demand for municipal services and infrastructure requires the availability of a reliable and sustainable stream of income for decentralized governments. Urbanization and decentralization have created the need for local governments to improve local revenue mobilization in order to enhance local infrastructure and services provision (Ellis et al., 2007).

The taxation of real estate property is the most progressive and assured way of raising stable, predictable and sufficient revenue stream for local authorities and facilitating fiscal decentralization (McCluskey et al, 2003). Property tax is also politically visible, and economically efficient (Qing and Guo, 2006; Monkam, 2011). It is neutral on its influence on tax payers' economic decisions and therefore constitutes an efficient means for local government units to mobilize revenue (Trasberg, 2004), and one of the best local taxes owing to the immovability of the tax base (Bird and Slack, 2002). The tax is well-suited for local governments to generate revenue for the financing of their infrastructure investments and the provision of municipal services (Keith, 1993; Kelly, 1998; Lall and Deichmann, 2006). Property tax is also least affected by short-term income and economic dynamics since properties exhibit long-term asset values appreciation.

Taxation of property helps to reduce the dependence of decentralized governments on central government funding, and is an important means for realising fiscal empowerment of local governments (Mathur, et. al. 2009). Property tax possesses the potential to impact positively on the fiscal autonomy of local authorities (McCluskey and Bevc, 2007). The tax strikes a balance between economic efficiency and fairness and hence much more acceptable to the local electorates (Davis et 
al, 2004). Property tax is an ideal tax for local governments in low-income countries since it serves as benefit levy, is progressive in its distribution of the tax burden, and has significant revenue-raising potential (Bahl, 2009). In addition, its ability to mobilize revenue for local authorities has immense potential as a tool for land and urban development policies (Kapoor and Ghosh, 1992). It is imposed for the purpose of mobilizing revenue for government, public purposes, infrastructure, municipal services, or land use planning (Needham, 2000). It is therefore an important component of local government finances in many nations.

The property tax system in most developing countries has several challenges. This may be the consequence of poor tax administration and policy. For instance, in most African countries, central governments hesitate to transfer property tax policy and administrative authority to local governments and are uninterested in the promotion of property tax reform (Kelly, 2000). The limited buoyancy of property taxation in developing and transitional countries may arguably be due to an under-developed fiscal decentralization regime (Bahl and Martinez-Vazquez, 2008). Property tax has been ineffective in low-income and transition countries partly because of legal exemptions, under-valuation, and low coverage ratios (Bahl, 2009). For example, the physical, financial and human resource capacity required for effective property taxation is a major challenge in east and southern African nations (Bird and Rodriguez, 1999; and Franzsen, 2002). The availability of professional valuers is central for the success of property rating. Despite the central role of property assessment to the success of any property rating regime professional expertise are generally lacking in most developing countries.

\section{Property taxation in the Offinso South Municipality}

The results of the field survey are presented in this section, with discussion of issues such as compliance rates, the role of land use planning, respondents' perceptions of rating officials, willingness to comply, and residents' expectations.

\section{Compliance with property rating in OSM}

The compliance rate with property taxation appears low in OSM. Table 1 (Panel A) indicates that $42.5 \%$ of the respondents did not pay property rates. A very high incidence of non-compliance will make the property tax less buoyant, (McCluskey et al, 2003). This appears to be the case in OSM. A non-compliance rate of $43 \%$ suggested by the data is extremely high. This has been complicated by the lack of enforcement against non-compliance partly because of political or bureaucratic interference, which undermines the efficiency of the tax collection system and enforcement against non-compliance (McCluskey et al, 2003; Lall and Deichmann, 2006). As one rating official said:

There is extreme interference in the prosecution of defaulters. There is complete lack of commitment on the part of the administration to implement enforcement decisions.

Large scale violations of property tax regulations as observed in OSM, however, make enforcement against non-compliance such as prosecution or seizures of property socially and politically imprudent. 
For enforcement to be successful its associated social and political cost should be minimal; this requires that the degree of non-compliance should be reasonably low.

Table 1: Compliance with Property Taxation in OSM

\begin{tabular}{|c|c|c|c|}
\hline \multicolumn{4}{|c|}{ Panel A: Compliance to Property Rate Payment (\%) } \\
\hline Paid Property Rate & Frequency & Percentage & Cumulative Percentage \\
\hline Yes & 69 & 57.5 & 57.5 \\
\hline No & 51 & 42.5 & 100 \\
\hline Total & 120 & 100 & \\
\hline \multicolumn{4}{|c|}{ Panel B: Demand Notice } \\
\hline $\begin{array}{l}\text { Received Demand } \\
\text { Notice }\end{array}$ & Frequency & Percentage & Cumulative Percentage \\
\hline Yes & 62 & 51.7 & 51.7 \\
\hline No & 58 & 48.3 & 100 \\
\hline Total & 120 & 100 & \\
\hline \multicolumn{4}{|c|}{ Panel C: Compliance to Demand Notice } \\
\hline Honoured Notice & Frequency & Percentage & Cumulative Percentage \\
\hline Yes & 47 & 75.8 & 75.8 \\
\hline No & 15 & 24.2 & 100 \\
\hline Total & 62 & 100 & \\
\hline
\end{tabular}

Table 1 (Panel B) suggests that $51.7 \%$ of the respondents received a property rate demand notice from OSMA, indicating low coverage. Also, Panel C (Table 1) shows that $24.2 \%$ of the respondents who received a property-rate demand notice from OSMA did not honour it, suggesting a low collection rate. The data show that out of the $57.5 \%$ of the respondents who paid the property rate only $68.1 \%$ were on OSM's valuation list and were thus issued a demand notice by the rating authority. The remaining $31.9 \%$ of the respondents either paid voluntarily or were prompted by OSMA's mobile property rate collectors. The data show that low coverage and collection ratios are partly responsible for the low property rate yield in the OSM.

\section{Land use planning and property rating in OSM}

Act 465 establishes the MMDAs as the planning and rating authorities of their jurisdictions. OSMA is thus the rating and planning authority in OSM. The Act makes it mandatory to obtain a building permit for all development (new developments, extensions to existing properties and change of use). Public discontent with the planning system is high, leading to large scale violations of the land use regulations in OSM (Boamah et al., 2012; Boamah, 2013). The evidence in this paper suggests that the violations of land use regulations appear to be linked to compliance with property rating. Table 2 indicates a statistically significant relationship between property rate payments and compliance with land use regulations in OSM (Chi-square 6.54, P-value 0.011). The data indicate that the respondents 
who applied for building permits for their properties are more likely to pay property rates $(75.6 \%$ compared to $59.8 \%$ for all respondents) and those who did not apply for building permits are more likely not to obey property rating regulations ( $48.7 \%$ in relation to $40.2 \%$ for all respondents). The Table further shows a statistically significant association between issuance of demand notice and the planning status of the property (Chi-square 9.87, P-value 0.002). Owners of approved properties are most likely to be issued property rate demand notice from OSMA whilst owners of unapproved properties are most likely not to receive one. The property owners may not be held responsible for defaulting property tax if they have not been billed. OSMA is thus largely to be blamed for the low property rate yield in OSM.

Table 2: Permit Applications and Property Rating in OSM

\begin{tabular}{|l|l|c|c|c|c|}
\hline \multirow{2}{*}{} & & \multicolumn{3}{|c|}{ Applied for Permit (\%) } & \multirow{2}{*}{ Pearson Chi-square } \\
\cline { 2 - 5 } & & Yes & No & Total & \\
\hline \multirow{2}{*}{$\begin{array}{l}\text { Paid } \text { Rate } \\
\text { Property }\end{array}$} & Yes & 75.6 & 51.3 & 59.8 & 6.54 \\
\cline { 2 - 5 } & No & 24.4 & 48.7 & 40.2 & $0.011^{\text {** }}$ \\
\cline { 2 - 5 } & Total & 100 & 100 & 100 & \\
\hline \multirow{2}{*}{$\begin{array}{l}\text { Received } \\
\text { Demand Notice }\end{array}$} & Yes & 77.9 & 45.5 & 55.9 & 9.87 \\
\cline { 2 - 5 } & No & 22.1 & 54.5 & 44.1 & $0.002^{\text {** }}$ \\
\cline { 2 - 5 } & Total & 100 & 100 & 100 & \\
\hline
\end{tabular}

Source: Author's Data, 2012,** p-value.

The significant association between the compliance rates for the property tax and the land use regulations may be due to general public disdain and lack of confidence in both the rating and planning systems in OSM. It is also possible that owners of unapproved properties may be afraid that by paying property tax they may be noticed and sanctioned for non-compliance with the land use regulations. This however, appears less likely since properties are very conspicuous and it does not require special effort to identify unauthorised properties. Also, enforcement against breach of land use regulations is virtually non-existent in OSM (Boamah, 2013). It appears that OSMA has not been able to capture the large number of unapproved properties in OSM on its valuation list, as evidenced by OSMA's inability to issue property rate demand notice to the owners of such buildings.

The relation between the planning system and property rating may be due to the degree of informality in the municipality. It is important to note however, that unapproved properties are generally of high quality and are located on approved residential areas and building lots. Land allocation is done by the Offinso Traditional Council (OTC) based on OSMA's approved land use plan. Developers are, however, expected to seek planning consent from the OSMA, but most developers ignore this after receiving land, leading to large numbers of unapproved properties in planned areas of OSM. Thus the significant positive correlation (Pearson 0.336, p-value 0.010) between the compliance rates for the land use and property tax regulations may be due to public disdain for both systems. 


\section{Perceptions of property tax payers about the attitudes of rating officials}

As shown in Table 3, there is also a statistically significant association between tax payers' perceptions of rating officials and compliance (Chi-square 9.24, P-value 0.002). The respondents who have positive perceptions about the attitudes of rating officials are more likely to recommend compliance to other property owners ( $94.5 \%$ relative to $89.4 \%$ of all respondents) whilst tax payers' who hold negative perceptions about rating officials are more likely not to recommend compliance to other property owners (36.4\% compared to $10.6 \%$ of all respondents). This shows that tax payers' who are satisfied with the attitudes of the rating officials are likely to honour future property rate demands and also encourage other property owners to pay. Similarly, the respondents who are dissatisfied are more likely not to honour future property rate obligations and also discourage others from property rate payments. This kind of ripple effect may be partly responsible for the large scale non-compliance with property taxation in OSM.

Table 3: Perceptions on Official Attitudes and Recommendations

\begin{tabular}{|c|c|c|c|c|c|}
\hline & & \multicolumn{3}{|c|}{ Perceptions on Official Attitude (\%) } & \multirow{2}{*}{$\begin{array}{l}\text { Pearson Chi- } \\
\text { square }\end{array}$} \\
\hline & & Positive & Negative & Total & \\
\hline \multirow{3}{*}{$\begin{array}{l}\text { Recommend } \\
\text { Payment }\end{array}$} & Yes & 94.5 & 63.6 & 89.4 & \multirow{3}{*}{$\begin{array}{c}9.24 \\
0.002^{\star \star}\end{array}$} \\
\hline & No & 5.5 & 36.4 & 10.6 & \\
\hline & Total & 100 & 100 & 100 & \\
\hline
\end{tabular}

Source: Author's Construct, 2012, ** p-value

\section{Public dislike for the imposition of property rate}

The data indicate that $58 \%$ of property owners agree with the imposition of property rate in OSMA and $42 \%$ disagree. Although, the proportion of the respondents supporting the property tax is higher than those with contempt for it, the $42 \%$ of the property owners who objected to the imposition of the tax is relatively high, which may partly explain the lack of buoyancy of property rate revenue in OSM. About $61.7 \%$ of respondents who dislike the property rate cite the misuse of property rate revenue and the absence of basic infrastructure and services in OSM, giving little justification for the property rate. The remaining $38.3 \%$ of respondents disliking the property tax mentioned socio-cultural reasons such as indigenous land rights as the reason.

Table 4: Agreement with Property Taxation and Neighbourhood Development

\begin{tabular}{|l|l|c|c|c|c|}
\hline \multirow{2}{*}{ Awareness } & \multicolumn{2}{|c|}{ Agree to Property Taxation (\%) } & \multirow{2}{*}{$\begin{array}{c}\text { Pearson Chi- } \\
\text { square }\end{array}$} \\
\cline { 3 - 5 } & & Yes & No & Total & \\
\hline $\begin{array}{l}\text { Benefited from } \\
\text { Property Rate }\end{array}$ & Yes & 83.3 & 16.7 & 100 & 8.23 \\
\cline { 2 - 5 } & No & 50.6 & 49.4 & 100 & $0.004^{\star \star}$ \\
\cline { 2 - 5 } & Total & 57.8 & 42.2 & 100 & \\
\hline
\end{tabular}

Source: Author's Construct, 2012, ** p-value. 
Table 4 shows a statistically significant relationship (Chi-square 8.2, P-value 0.004) between respondents' support for the property tax and its perceived benefits, as those who have benefited from property tax investments in their communities generally support its imposition (83.3\% relative to $57.8 \%$ for all respondents). Those who perceive that their neighbourhoods have not gained from the property tax are more likely to hold the tax in contempt (49.4\% relative to $42.2 \%$ of respondents). Table 5 indicates that respondents who are unopposed to the property tax are more likely to pay (67.7\% compared to $61.3 \%$ of all respondents), and those who oppose the property tax are more likely not to pay ( $47.8 \%$ relative to $38.7 \%$ of all respondents). The result indicates that public disdain for the property tax regime has had negative impact on the buoyancy of property tax revenue in OSM.

Table 5: Agreement with Property Taxation and Compliance

\begin{tabular}{|c|c|c|c|c|c|}
\hline \multirow{2}{*}{ Awareness } & & \multicolumn{3}{|c|}{ Agree to Property Taxation (\%) } & \multirow{2}{*}{$\begin{array}{l}\text { Pearson Chi- } \\
\text { square }\end{array}$} \\
\hline & & Yes & No & Total & \\
\hline \multirow{3}{*}{$\begin{array}{l}\text { Paid Property } \\
\text { Rate }\end{array}$} & Yes & 67.7 & 52.2 & 61.3 & \multirow{3}{*}{$\begin{array}{c}2.73 \\
0.098^{\star \star}\end{array}$} \\
\hline & No & 32.3 & 47.8 & 38.7 & \\
\hline & Total & 100 & 100 & 100 & \\
\hline \multirow{3}{*}{$\begin{array}{l}\text { Honored } \\
\text { Demand Notice }\end{array}$} & Yes & 85.3 & 67.9 & 77.4 & \multirow{3}{*}{$\begin{array}{c}2.67 \\
0.102^{\star *}\end{array}$} \\
\hline & No & 14.7 & 32.1 & 22.6 & \\
\hline & Total & 100 & 100 & 100 & \\
\hline
\end{tabular}

Source: Author's Construct, 2012, ** p-value.

\section{Respondents expectations from the property tax}

The relatively high public disdain for the property tax in OSM may be due to unmet public expectations. Table 6 indicates that 25\%,10\%,27.5\% and $8.3 \%$ of the respondents expect OSMA to invest property tax revenue in general infrastructure and service delivery, education, urban roads and utility provision.

Table 6: Respondents Expectations from Property Taxation

\begin{tabular}{|l|c|c|c|}
\hline Reason & Frequency & $\begin{array}{c}\text { Percentag } \\
\text { e }\end{array}$ & $\begin{array}{c}\text { Cumulative } \\
\text { Percentage }\end{array}$ \\
\hline $\begin{array}{l}\text { General Infrastructure and Service } \\
\text { provision* }\end{array}$ & 30 & 25 & 25 \\
\hline Education & 12 & 10 & 35 \\
\hline Urban Roads & 33 & 27.5 & 62.5 \\
\hline Utility & 10 & 8.3 & 70.8 \\
\hline Proper Waste Management & 4 & 3.3 & 74.1 \\
\hline Public Toilets & 16 & 13.3 & 87.4 \\
\hline Security & 1 & 0.8 & 88.2 \\
\hline Markets & 2 & 1.7 & 89.9 \\
\hline No Response & 12 & 10 & 100 \\
\hline Total & 120 & 100 & \\
\hline
\end{tabular}

Source: Author's Construct, 2012. * Respondents could select more than one option (e.g. education and utility). 
Visible evidence in the municipality shows that facilities are generally inadequate. Educational infrastructure is limited and some schools have been maintained for forty years. Urban roads are lacking and some neighbourhoods are without access roads. Households' access to piped water and electricity and is also limited in some neighbourhoods. Public disdain for the property tax and the limited buoyancy of property tax revenue may also due to these unsatisfied public expectations.

\section{Policy implications of the findings}

High non-compliance rates, lack of enforcement against compliance, general public disdain, and negative perceptions about rating officials all seem to have contributed to low property tax yield in OSM. The data indicate that the respondents who are dissatisfied with the municipal authority's disbursement of the property tax revenue are less likely to pay the property tax and are even more likely to discourage others from paying. Due to the extended nature of the family system and strong socio-cultural relationships amongst property owners in OSM, the ripple effect of public contempt on voluntary compliance could be severe. It is thus important for OSMA to be transparent in the use of the property rate, making reasonable investments in urban infrastructure such as education and access roads which may have the potential to encourage voluntary compliance, as the field data suggest that a major constraint to the success of the property tax in OSM is the widespread perception that proceeds are misused and not invested in community services. Public confidence in the tax system is essential for the success of property taxation (Bahl, 2009). OSMA should purge the property tax of perceived corruption and negative official attitudes, which has the potential to encourage compliance, and reduce the social and political cost of enforcement.

The field data also suggest a strong association between the planning system and property tax in OSM. Property owners who complied with the planning system or are satisfied with the planning system are more likely to comply voluntarily with the property tax. This link between the planning system and the property tax may be due to public contempt for both systems, or to socio-cultural factors perhaps because a property that is formal in one aspect is likely to be formal in others. Efforts at improving the land use planning system may thus yield dividends for the property tax system, so it may be important for OSMA to address the inherent problems in its land use planning regulations. We argue that developers who successfully secure building permits with few hurdles tend to have confidence in the municipal authority and subsequently comply with the authority's property rate regulations. An improved land use planning system will also make it easier for OSMA track new developments and update its valuation list regularly. Improving the land use planning system will also reduce the degree of informal development; encourage compliance with the property tax; enhance the coverage and collection rates, and thus increase the yields to OSM.

Comprehensive reforms of the property tax regime incorporating property data collection and valuation, tax assessment and collection, and enforcement against non-compliance are needed in 
OSM, but administrative, regulatory, and technical shortfalls may undermine efficiency of the property-tax collection system and enforcement against non-compliance (Lall and Deichmann, 2006). Thus it may be appropriate for OSMA to employ GIS techniques and a tax-mapping system in property identification to capture all properties within its jurisdiction, both taxable and non-taxable, on the tax roll. A high coverage ratio is a prerequisite for successful mobilization of the property rate.

However, OSMA has no qualified valuation professionals in-house though trained and certified valuers are not scarce in Ghana. What is needed is an efficient state institutional framework to utilize their expertise in ensuring efficient property-rate administration in the country. OSMA staff indicated that they lack legal powers to recruit rating officers directly, but have to get approval from the head of the Civil Service of Ghana or the Local Government Secretariat, and the municipality has not been successful in securing such an approval.

The lack of qualified professionals to manage the property tax regime is a major obstacle to optimising property tax revenue in OSM. It is thus important for central government to remove the bureaucratic obstacles for decentralized governments in recruiting valuation professionals to enhance the property tax administration and maximize property rate revenue in the country. It is equally important for OSMA to strengthen the property tax administration system in the municipality. A weak system for administering property tax may lead to an inequitable distribution of the tax burden and surge public disdain against it (Monkam, 2011). An improved administration is essential for the buoyancy of property tax revenue (Kelly, 2000), and is vital to ensure that all properties within the authority's jurisdiction are captured on the tax roll, so that there is adequate valuation, accurate tax assessment, adequate collection and enforcement.

\section{Conclusion}

The study clearly shows that an inadequate property tax administration system, inadequate personnel, increased public contempt and perceived corruption have undermined the property tax system in OSM. Limited coverage of the tax base, inaccurate valuations, and inadequate enforcement and collection are partly responsible for poor collection rates, and it may be difficult for OSMA to justify the payment of the property rate without improving services and infrastructure in the municipality. It is recommended that OSMA strengthens the enforcement of property tax collections, expands the coverage ratio, regularly updates the valuation list, and computerises the billing and collection process in order to improve property rate mobilization in OSM. OSMA should also remove bottlenecks in its land use planning system since compliance with this is likely to translate to compliance with the property tax. OSMA should further ensure accountability and transparency in the property tax administration system in the municipality. 


\section{References}

Adem, M. N. and Kwateng, O. A. (2007) Review of Real Property Tax Administration in Ghana, Master of Science Thesis, Number 381, Department of Real Estate and Construction Management, Royal Institute of Technology, Stockholm, Sweden.

Bahl, R. (2009) Property Tax Reform in Developing and Transition Countries, Fiscal Reform and Economic Governance Project, United States Agency for International Development.

Bahl, R., and Martinez-Vazquez, J. (2008) The Determinants of Revenue Performance in Roy Bahl, Jorge Martinez-Vazquez and Joan Youngman, (ed) Making the Property Tax Work: Experiences in Developing and Transitional Countries, Cambridge MA: Lincoln Institute of Land Policy

Baldersheim, H., Illner, M., Offerdal, A., Rose, L. and Swianiewicz, P. (1995) Local Democracy and the Process of Transformation in East-Central Europe, Oxford:Westview Press,

Bell, M. (1999) An Optimal Property Tax: Concepts and Practices, World Bank, Washington, D.C.

Bird, R. and Rodriguez, E.R. (1999) Decentralization and Poverty Alleviation. International Experience and the Case of the Philippines, Public Administration and Development, Vol. 19, 299-319.

Bird, R. and Slack, E. (2002) Land and property taxation around the world: a review, Journal of Property Tax Assessment and Administration, 7(3)31-80.

Boamah, N.A. (2013). Land use controls and residential land values in the Offinso South municipality, Ghana. Land Use Policy (2013), http://dx.doi.org/10.1016/j.landusepol.2012.12.016

Boamah, N. A. (2012) Housing for the vulnerable in the Offinso South Municipality of Ghana. Housing, Care and Support, 15(3) 140-147.

Boamah, N. A., Gyimah, C., and Nelson, J.K.B. (2012) Challenges to the Enforcement of Development Controls in the Wa municipality, Habitat International. 36 (1) 136-142.

Braid, R. M. (2005) Tax Competition, Tax Exporting and Higher-Government Choice of Tax Instruments for Local Governments, Journal of Public Economics,. 89, pp. 1789-1821.

Davis, P.T., McCluskey, WJ and Lim, Lay Cheng (2004) "Residential Property Taxation: A Capital Value Banding Approach”, Journal of Property Tax Assessment and Administration. 1 (3) 51-64.

De Cesare, C. M. (2004) General Characteristics of Property Tax Systems in Latin America Paper presented at 7th International conference on Optimizing Property Tax Systems in Latin American, Guadalajara, Jalisco, Mexico.

Ellis, P.; Mihaly, K.; and Lee, A. G. (2007) Property Taxes in the Large Cities of Punjab Province, Pakistan, Journal of Property Tax Assessment and Administration, 4(2) 31-51.

Franzsen, R.C.D. (2002) An Overview of Property Taxation in Southern and East Africa: Problem Areas and Possible Lessons, paper presented at the International Property Tax Institute (IPTI) and Ministry of Finance, Czech Republic Workshop on Property Taxation in Transition, Prague, Czech Republic.

Ghana Statistical Service (2005). 2000 Population and Housing Census, Ashanti Regional Analysis. Accra: GSS.

Government of Ghana (2011) Budget Statement. Accra, GoG.

Hefferan, M. J. and Boyd. T. (2010) Property taxation and mass appraisal valuations in Australia-adapting to a new environment, Property Management, 28 ( 3) 149-162.

Kaiser, K. (2005) Intergovernmental fiscal relations in Pakistan-Structural challenges for the 2001 devolution. Washington, DC: The World Bank.

Kapoor, R. M. and Ghosh, P. K., (1992) Composite Area Linked System for Property Tax Reform in India, Review of Urban and Regional Development Studies, Vol. 4, pp. 209-225.

Keith, S. (1993) Property Tax in Anglophone Africa: A Practical Manual, World Bank Technical Paper Number 209, Washington, DC, United States.

Keith, S. and McCluskey, W. (2004) Decentralization and Rural Property Taxation. FAO Land Tenure Studies. FAO: Rome 
Kelly, R. (1998) Designing Property Tax Reform Strategies in Developing Countries: An Analytical Framework Applied to Kenya, Harvard Institute for International Development, Working Paper Series, Harvard University, Cambridge, Massachusetts, United States, pp 1-31.

Kelly, R. (2000) Designing a Property Tax Reform Strategy for Sub-Saharan Africa: An Analytical Framework Applied to Kenya, Public Budgeting and Finance; Winter, 2000.

Kwakye, J. K. (2010) Overcoming Africa's Addiction to Foreign Aid: A Look at Some Financial Engineering to Mobilize Other Resources, Institute of Economic Affairs (IEA), Monograph No. 32: 2010.

Lall, S. V. and Deichmann, U. (2006) Fiscal and Distributional Implications of Property Tax Reforms in Indian Cities, Working Paper No. 39 April 2006, National Institute of Public Finance and Policy, New Delhi.

Livingstone, I. and Charlton, R. (1998) Raising local authority district revenues through directtaxation in a lowincome developing country: evaluating Uganda's GPT, Public Administration and Development, Vol. 18: 499517.

Mathur, O. P., Bahl, R., Thakur, D., and Rajadhyasksha, N. (2009) Urban Property Tax Potential in India, New Delhi: National Institute of Public Finance and Policy.

McCluskey, W. J. and Bevc, I. (2007) Fiscal decentralization in the Republic of Slovenia: an opportunity for the property tax, Property Management, 25(4), 2007 pp. 400-419.

McCluskey, W., Franzsen, R., Johnstone, T., and Johnstone, D. (2003) Property Tax Reform: the Experience of Tanzania, Our Common Estate, July 2003.

Monkam, N. F. (2011) Property Taxation in Senegal: Legislation and Practice, Journal of Property Tax Assessment and Administration, 8(3) 41-60.

Mou, C. (1996) Major Property Tax Issues in Africa, PropertyTax in Eastern and Southern Africa: Challenges \& Lessons Learned, Working Paper, No.2, Harare Zimbabwe: Municipal Development Programme, 4-9.

Needham, B., (2000) Land Taxation, Development Charges, and the Effects on Land-Use, Journal of Property Research, 17(3) 241-257.

Obeng-Odoom, F. (2010) Is Decentralisation in Ghana pro-poor? Commonwealth Journal of Local Governance, Is. 6: July 2010.

Okrah, M. and Boamah, N. A. (2013) Deepening Representative Democracy through Fiscal Decentralisation: Is Ghana Ready for Composite Budgeting?, AFRREV IJAH, Vol.2 (2), pp. 73-90.

Qing, Z. and Guo, X. J. (2006) The Modernization of Real Estate Taxation in China, Journal of Property Tax Assessment and Administration, 3(4) 5-12.

Rao, U.A.V and A. Ravindra, (2002) Reforming the Property Tax. New Delhi: UNDP.

Trasberg, V. (2004) Property and land taxation in the Baltic States, Journal of Property Tax Assessment and Administration, 1 (2): 31-43.

Varanyuwatana, S. (1999) Property Tax in Thailand in William McCluskey (ed), Property Tax: An International Comparative Review, Aldershot: Ashgate pp. 148-163. 